\title{
Market Reaction to Dividend Announcement: Evidence from Turkish Stock Market
}

\author{
Eyüp Kadığlu ${ }^{1}$, Niyazi Telçeken ${ }^{1} \&$ Nurcan Öcal ${ }^{1}$ \\ ${ }^{1}$ Capital Markets Board, Ankara, Turkey \\ Correspondence: Eyüp Kadığlu, Capital Markets Board, Ankara, Turkey. E-mail: eyup.kadioglu@gmail.com
}

Received: June 24, 2015

Accepted: July 13, 2015

Online Published: August 25, 2015

doi:10.5539/ ibr.v8n9p83

URL: http://dx.doi.org/10.5539/ ibr.v8n9p83

\begin{abstract}
:
This study investigates market reactions to cash dividend announcements by analyzing abnormal returns around the declaration date in Borsa Istanbul. The study applies a panel regression method to a data set including 902 announcement made by 118 companies during the period from 2003 to 2015. It is found that there is a significant, negative relationship between cash dividends per share and abnormal returns following the announcement of dividends. Thus, the results support the tax-clientele effect hypothesis. When a given company announces cash dividends, shareholders start to sell their holdings in order to avoid more taxation in the future; therefore, market prices decrease. Furthermore, the results suggest that there is no statistically significant information leakage prior to the announcement date, and it seems that the inefficiency of the market decreases over time as prices adapt to new information more quickly.
\end{abstract}

Keywords: cash dividend, announcement effect, market reaction, tax-clientele effect hypothesis, Borsa Istanbul

\section{Introduction}

The relationship between dividends and a firm's value or a firm's share price has been researched for more than fifty years. Theories have been developed and tested through several empirical studies. However, it is still a puzzle as to whether or not dividends have an effect on the value of a firm or a firm's stock price.

It is generally accepted that dividend changes affect the stock price around the disclosure date of dividend. Therefore, many legal bodies including the Turkish authority accept that dividend announcements affects stock price. However, some empirical studies conclude that stock price is not affected by disclosure of dividend.

The information signaling theory, the free cash flow hypothesis and the dividend clientele effect hypothesis are three major theories attempting to explain the effect of dividend announcements on share prices.

The tax-clientele effect, formulized by Miller and Modigliani (1961) and Black and Scholes (1974), argues that some firms attract investors by tailoring their dividend policy to investors' tax preferences. If capital gains are taxed at a lower rate, for instance, then shareholders will want earnings to be retained by the firm.

Many studies have examined market reactions to cash dividend announcements by analyzing abnormal returns around the announcements date. Ang (1975), Gonedes (1978) and Watts (1973) found that unexpected changes in dividends cause little or no abnormal returns. On the other hand, Pettit $(1972,1976)$, Charest (1978), Aharony and Swary (1980), Woolridge (1982), Asquith and Mullins (1983), Kalay and Lowenstein (1985), and Akhigbe and Madura (1996) document that market reacts positively to announcements of dividend increases while market reacts negatively to dividend decreases.

This study investigates market reactions to cash dividend declarations by analyzing abnormal returns around the announcement date in Borsa Istanbul using a longer period of analysis, more recent data and more advanced methods.

The data are collected from the Borsa Istanbul website for the period prior to 2010 and the Public Disclosure Platform (PDP) website for the period after 2010. Although the material events and the price data are publicly available, each announcement date has to be collected manually for the period before 2010. Borsa Istanbul publishes the closing price of each company and the market index XUTUM, which contains the weighted prices of all companies. Our sample consists of thirteen years of data (2003-2015) documenting 902 cash dividend announcements of 118 listed companies. 
The fixed effect panel regression analysis is used to test the effects of dividend per share (DPS) on share prices by investigating the existence of abnormal returns around the declaration dates of dividends. The market-adjusted model employed to calculate excess returns within the event window, taking the announcement date as the starting point and looking both 10 days prior to and 30 days following the date. The event windows are determined to examine both the possibility of information leakage prior to the declaration date as well as price adjustment based on new information following the disclosure date. In the fixed effect panel regression analysis, dividend-per-share is regressed on cumulative abnormal returns $(C A R)$ along the event windows. This study documented that market reacts negatively to disclosure of cash dividend following the declaration of dividends. The results support the tax-clientele effect hypothesis. When a company announces cash dividends, shareholders start to sell their holdings in order to avoid more taxation in the future. Therefore, market prices of shares decrease significantly.

This study differs from those of Aydoğan and Muradoğlu (1998), Muradoğlu and Aydoğan (2003), and Batchelor and Ortakçıoğlu (2003) in two ways: Firstly, this study provides evidence about the announcement effect of cash dividends by using a larger, more recent data set (2003 to 2015). Previous work on dividends in Turkey was undertaken when the economy was suffering from high inflation and when Borsa Istanbul was in its formative stage. However, Turkish capital markets have developed rapidly since the end of the 1980s, and the economy has both has passed through a number of economic and financial crises and undergone many structural reforms. By using data from the period 2003 to 2015, therefore, our study is better able to assess the effects of cash dividends on prices. Secondly, instead of collecting declaration dates by mail or by using proxies for them, this study uses the exact declaration dates. This study also introduces new methodology, and uses a more extensive sample size and period of analysis as compared to those of Günalp, Kadığlu and Kılıç (2010) and Yılmaz and Selçuk (2010).

Section 2 of the study provides an overview of the relevant literature. Section 3 introduces the data and methodology while Section 4 presents the empirical results and their implications. Finally, Section 5 summarizes the conclusions of the study.

\section{Literature Review}

The stock price reaction to disclosure of dividend is mainly explained by the information signaling theory, the free cash flow hypothesis and the dividend clientele effect hypothesis.

The notion of the information content of dividends was first proposed by Lintner (1956) and Miller and Modigliani (1961). It was subsequently formalized by Bhattacharya (1979), John and Williams (1985) and Miller and Rock (1985) as the signaling theory. Although Miller and Modigliani (1961) held that dividends have no effect on the value or capital structure of a firm under perfect market conditions, they proposed that dividends convey information about a firm's future earnings and cash flows. They argued that the managers of a given firm have insider knowledge about future prospects of the firm, which leads to asymmetric information between managers and shareholders. Therefore, dividends are used to reduce the level of asymmetric information.

Managers have insider knowledge about the future earnings and cash flows of a firm, and the disclosure of dividends is one way of communicating this information to shareholders. Managers announce an increase in the current dividend as a way to inform shareholders about an increase in the firm's future cash flows. In other words, dividend changes convey valuable information about permanent changes in the firm's future earnings, and share prices reflect this change following the dividend announcement.

The information signaling hypothesis is tested by examining the relationship between current dividends and future earnings or the stock price reaction to dividend around the disclosure date. Besides testing the earnings-dividend relationship, many studies have investigated the causality effect of dividends on share prices by analyzing abnormal returns around the dividend declaration date. Although Ang (1975), Gonedes (1978) and Watts (1973) found that surprised change in dividends had little or no effect, Pettit (1972, 1976), Charest (1978), Aharony and Swary (1980), Woolridge (1982), Asquith and Mullins (1983), Kalay and Lowenstein (1985) and Akhigbe and Madura (1996) concluded that the stock price reacted positively to dividend increases or stock price reacted negatively to dividend decreases.

The free cash flow hypothesis takes the agency theory, proposed by Jensen (1986), as a basis for explaining this phenomenon. According to Jensen, managers are reluctant to pay out dividends, as they want the greatest amount possible of free discretionary cash flow. A greater amount of free cash flow allows managers to invest in projects that have negative net present value and to use cash for their self-interest. Dividends play a key role, as they can be used to decrease the free cash flow, thus lowering the agency cost. 
According to Jensen (1986), dividends are used as a mechanism to monitor and discipline managers rather than a direct shareholder intervention into management affairs. Therefore, an increase in dividends communicates positive information in which the agency cost will be reduced and investing in projects with negative net present value will be less likely in the future. If managers announce an increase in dividends, the free cash flow will be less in the future. Thus, the announcement of dividend increases implicitly states that the performance of the company will be better in the future. As a result, the dividends have information content in which the behavior of managers will be more aligned with the interest of shareholders, and the managers are more likely to invest in projects that have positive net present value. The studies of DeAngelo and DeAngelo (2000), La Porta et al. (2000), Rozeff (1982) and Easterbrook (1984) support the free cash flow hypothesis while the study of Dennis et al. (1994) do not support it.

The dividend clientele effect hypothesis argues that some shareholders prefer earnings to be paid out as dividends while others prefer earnings to be retained by the firm due to the difference in taxation rates between capital gains and dividend yields. Black and Scholes (1974) and Miller and Scholes (1982) claim that if capital gains are taxed at a lower rate, there should be no relation between dividends and stock price. The relationship between favorable taxation of capital gains was formulized as the tax-clientele effect hypothesis by Miller and Modigliani (1961) and Black and Scholes (1974). The hypothesis argues that some firms attract shareholders because the firm's dividend policy suits investors' tax preferences. If capital gains are taxed at a lower rate, then shareholders want earnings to be retained by the firm. Conversely, if dividend payouts increase, shareholders will sell their shares avoid paying taxes higher than those levied on capital gains. If both are taxed equally, shareholders will be indifferent to policies regarding dividend yields and capital gains. Black (1976) states that this is as a puzzle; while dividends have no effect on the value of a firm, firms still pay dividends.

Table 1. summarizes some other recent empirical studies analyzing market reaction to dividend around the dividend declaration date.

Table 1. Summary of studies on the announcement effects of dividends

\begin{tabular}{|c|c|c|c|c|c|}
\hline Authors & Country & \# of firm s & \# of div. & Period & Result \\
\hline $\begin{array}{l}\text { Vazakidis and Athianos } \\
\text { (2010) }\end{array}$ & Greece & 60 & & 2004-2008 & $\begin{array}{l}\text { Negative market reaction throughout the } \\
\text { post-announcement period. }\end{array}$ \\
\hline Lukose and Rao (2010) & India & & 9,523 & 1993-1998 & Market reacts positively to dividend initiations \\
\hline Sharma 2011 & India & 133 & 1,188 & $1997-2007$ & No market reaction to dividend \\
\hline Akron (2011) & Israel & 25 & 209 & 2001-2007 & $\begin{array}{l}\text { Significant, positive reaction to first-day dividend } \\
\text { announcement }\end{array}$ \\
\hline Miletic (2011) & Croatia & 32 & 46 & 2007-2009 & Market reacts positively to dividend \\
\hline $\begin{array}{l}\text { Sheikhbahaei et al. } \\
\text { (2011) }\end{array}$ & Malaysia & 138 & 356 & 2008-2011 & Market reacts positively to dividend increasing stocks \\
\hline Suwanna (2012) & Thailand & 60 & & 2005-2010 & Market reacts positively to dividend \\
\hline Demontis (2013) & $\begin{array}{l}\text { Scandinavian } \\
\text { countries }\end{array}$ & 812 & & 2005-2012 & $\begin{array}{l}\text { Market reacts positively for dividend increase } \\
\text { announcements. }\end{array}$ \\
\hline Mamun et al. (2103) & Bangladesh & & 89 & 2011-2011 & Market reacts negatively to dividend \\
\hline Perepeczo (2014) & Latvia & & 170 & 1991-2011 & Market reacts positively to dividend initiations \\
\hline Samwel et al. (2014) & Kenya & 57 & & $2006-2010$ & Market reacts negatively to dividend \\
\hline Liu and Chi (2014) & Taiwan & & 5870 & $2000-2010$ & Market reacts positively to dividend \\
\hline Pan et al. (2014) & Chinese & 1475 & 12538 & 1993-2006 & No market reaction to dividend \\
\hline Asiri (2014) & Bahrain & 40 & 157 & 2004-2013 & Market reacts positively to dividend \\
\hline Abbas (2015) & Syria & 11 & 18 & 2010-2014 & Market reacts negatively to dividend \\
\hline
\end{tabular}

Studies on this issue in an emerging market such as Turkey are limited. Earlier work on Turkey includes Aydoğan and Muradoğlu (1998), Muradoğlu and Aydoğan (2003) and Batchelor and Orakçığlu (2003). All of these studies used data from the 1990s, and generally did not use exact declaration dates. They focused on share dividends and share repurchases.

Yılmaz and Selçuk (2010) investigated market reactions to dividend change announcements in Borsa Istanbul using a sample of 184 announcements made by 46 companies during the period from 2005 to 2008 . They used classical event study methodology. Their results suggested that the market reacts positively to dividend increases, negatively to dividend decreases, and does not react when dividends remain unchanged. 
Günalp, Kadıoğlu and Kılıç (2010) investigated the information content of cash dividends by using ordinary least square regression analysis. Data used in the study consisted of 321 cash dividend announcements and relevant share prices of 83 companies traded on Borsa Istanbul during the period from 2003 to 2007. They concluded that there is a significant, negative relationship between cash dividends and abnormal returns following the dividend announcements.

\section{Data and Methodology}

\subsection{Data}

The data used in this study is collected from the Borsa Istanbul website for the period prior to 2010 and from the PDP website for the period after 2010. According to the Turkish capital markets regulations, all listed companies have to report their material events as soon as possible via an electronic disclosure system used by Borsa Istanbul. According to the regulation, a dividend payout decision made by a board of directors is considered a material event, and it must be disclosed. These material events are generally reported on the day of or the day following their announcement. They are then are documented electronically under the name of each company, and a given company has one document listing all material events prior to 2010. Although the material events and the price data are publicly available, each announcement date has to be collected manually for the period prior to 2010. Since 2010, listed companies have to disclose their material events to the PDP.

Borsa Istanbul publishes the closing price of each company on the market index XUTUM, which contains the weighted price data of all companies. Daily returns are calculated as a percentage change in the closing price over successive days.

The sample consists 902 cash dividend of 118 listed companies during the period from 2003 to 2015.

Table 2. Descriptive statistics of event window cumulative abnormal returns

\begin{tabular}{|c|c|c|c|c|c|c|c|}
\hline Window & Mean & Median & Maximum & Minimum & Std. Dev. & Skewness & Kurtosis \\
\hline$[\mathrm{t}-10$ to $\mathrm{t}=1]$ & 0.0084 & -0.0001 & 0.5377 & -0.5181 & 0.0682 & 1.2068 & 15.5990 \\
\hline$[\mathrm{t}-5$ to $\mathrm{t}=1]$ & 0.0045 & 0.0001 & 0.2523 & -0.2032 & 0.0480 & 1.0817 & 6.9297 \\
\hline$[\mathrm{t}-3$ to $\mathrm{t}=1]$ & 0.0020 & -0.0004 & 0.2141 & -0.1434 & 0.0406 & 0.8124 & 6.1384 \\
\hline$[\mathrm{t}-2$ to $\mathrm{t}=1]$ & 0.0011 & -0.0010 & 0.1941 & -0.1646 & 0.0372 & 0.5861 & 6.3420 \\
\hline$[\mathrm{t}-1$ to $\mathrm{t}=1]$ & 0.0005 & -0.0007 & 0.2016 & -0.2014 & 0.0350 & 0.3693 & 8.0154 \\
\hline$[\mathrm{t}=0$ to $\mathrm{t}=0]$ & 0.0010 & -0.0002 & 0.1704 & -0.1662 & 0.0305 & 0.1641 & 9.6876 \\
\hline$[\mathrm{t}=0$ to $\mathrm{t}+1]$ & -0.0010 & -0.0018 & 0.1892 & -0.2872 & 0.0439 & -1.0144 & 12.0806 \\
\hline$[\mathrm{t}=0$ to $\mathrm{t}+2]$ & -0.0014 & -0.0025 & 0.3359 & -0.3095 & 0.0482 & -0.4674 & 12.2555 \\
\hline$[\mathrm{t}=0$ to $\mathrm{t}+3]$ & -0.0035 & -0.0035 & 0.3745 & -0.3237 & 0.0535 & -0.5563 & 11.8488 \\
\hline$[\mathrm{t}=0$ to $\mathrm{t}+5]$ & -0.0043 & -0.0045 & 0.3745 & -0.4684 & 0.0596 & -0.7281 & 12.4297 \\
\hline$[t=0$ to $t+10]$ & -0.0007 & -0.0050 & 0.5206 & -0.4841 & 0.0787 & 0.1111 & 11.0200 \\
\hline$[t=0$ to $t+15]$ & 0.0020 & -0.0039 & 0.6255 & -0.9420 & 0.0965 & -0.3522 & 18.5140 \\
\hline$[\mathrm{t}=0$ to $\mathrm{t}+20]$ & 0.0036 & -0.0013 & 0.7846 & -0.9473 & 0.1073 & 0.2175 & 16.4534 \\
\hline$[\mathrm{t}=0$ to $\mathrm{t}+25]$ & -0.0012 & -0.0119 & 1.4773 & -0.9523 & 0.1244 & 2.1316 & 32.1926 \\
\hline$[\mathrm{t}=0$ to $\mathrm{t}+30]$ & -0.0075 & -0.0179 & 1.6086 & -0.9539 & 0.1327 & 2.2156 & 33.0459 \\
\hline
\end{tabular}

Note. All values are in percentages, $\mathrm{t}$ is the announcement day, [ ] shows the inclusion of the day

$C A R$ is defined as the cumulative difference between the returns of individual shares and the returns on market indices during event windows 10 days prior to and 30 days following the declaration date. Table 2 presents the descriptive statistics of the cumulative abnormal returns along with event window, which are calculated using the market-adjusted model. The Table 2 gives mean, median, maximum, minimum, standard deviation, skewness and kurtosis values of cumulative abnormal returns within the event windows.

The data set includes dividend per share as a ratio of dividend payout to the nominal value a single share, which is 1 Turkish lira (TL). Table 3 gives the descriptive statistics of DPS from 2003 to 2015. Data for the whole period is presented in the final row. 
Table 3. Descriptive statistics of dividend per share

\begin{tabular}{ccccc}
\hline Year & Mean & Maximum & Minimum & St. Deviation \\
\hline 2003 & 2.3036 & 25.8000 & 0.0551 & 6.1891 \\
2004 & 0.3759 & 2.0000 & 0.0121 & 0.4417 \\
2005 & 0.9229 & 26.1500 & 0.0228 & 3.2541 \\
2006 & 1.1489 & 21.0000 & 0.0248 & 2.9639 \\
2007 & 1.7237 & 30.2000 & 0.0085 & 5.1511 \\
2008 & 1.3234 & 19.2200 & 0.0105 & 3.0357 \\
2009 & 0.8838 & 14.0000 & 0.0138 & 2.1893 \\
2010 & 0.5850 & 6.2000 & 0.0160 & 1.0671 \\
2011 & 0.5501 & 6.5774 & 0.0222 & 1.0985 \\
2012 & 0.9164 & 14.5000 & 0.0150 & 2.1488 \\
2013 & 0.7209 & 16.4200 & 0.0031 & 1.8039 \\
2014 & 0.6698 & 5.6212 & 0.0295 & 1.1207 \\
2015 & 0.8225 & 10.0000 & 0.0324 & 1.5930 \\
$2003-2015$ & 0.9169 & 30.2000 & 0.0031 & 2.5977 \\
\hline
\end{tabular}

As seen in Table 3, DPS does not radically change from year to year, but rather, decreases overall. On average, companies paid out $0.92 \mathrm{TL}$ of nominal value for each share $(1 \mathrm{TL})$. The minimum dividend is $0.03 \mathrm{TL}$ and the maximum dividend is $30.20 \mathrm{TL}$ per share. The standard deviation of DPS is $2.60 \mathrm{TL}$, which is above average.

\subsection{Methodology}

This paper investigates whether or not DPS plays a significant role in explaining market reaction resulting from dividend announcements. Panel regression analysis is used in an attempt to answer this question.

The event study utilizes traditional methodology (Armitage, 1995) commonly used to test for the announcement effects of dividends (Pettit, 1972; Masulis, 1980; Brown \& Warner, 1980; Aharony \& Swary, 1980; Woolridge, 1982; Asquith \& Mullins, 1983; Venkatesh, 1989; Akhigbe \& Madura, 1996), the announcement effects of earnings (Dennis \& McConnel, 1986), and the existence of insider trading (Sivakumar \& Waymire, 1994, Gregory et al., 1997; Hillier \& Marshall, 2002).

The first step in the study is to find daily returns of shares and market index. The original data is in the form of closing prices of shares and closing values of market index. Equation (1) is used to find the daily return of a share $i$ on day $t$. The numerator is the percentage change in closing price over successive days.

$$
R_{i t}=\left(P_{i t}-P_{i t-1}\right) / P_{i t-1}
$$

Here $R_{i t}$ is the daily return of share $i$ on day $t$, while $P_{i t}$ is the closing price of share $i$ at day $t . P_{i t-l}$ is the closing price of share $i$ on day $t-1$. The daily returns of market indices are calculated in the same way using the value of Borsa Istanbul XUTUM index over two successive days.

Equation (2) is used to find the daily abnormal returns of individual shares for each day.

$$
A R_{i t}=R_{i t}-M_{t}
$$

$A R_{i t}$ represents the daily abnormal return of share $i$ on day $t$, and $M_{t}$ represents the market index return on day $t$. The event study analysis performed here makes use of the market-adjusted model to estimate abnormal returns, while some other studies have used the market risk-adjusted model. The market-adjusted model assumes a value of 1 for the beta coefficient, which measures the risk level of each share. It also assumes a value of 0 for the intercept term. In contrast, the market risk-adjusted model calculates the beta coefficient by regressing daily market index returns on the daily share returns in a neutral period. Many researchers have argued that the market risk-adjusted model is not superior to the market-adjusted model (Armitage, 1995; Brown \& Warner, 1980). However, Marsh (1979) proposed that in cases of limited data, the risk-adjusted model reduces statistical efficiency. However, many researchers have found that the market-adjusted model provides results as good as the market risk-adjusted model when examining small markets. The studies of Liljeblom (1989), Martikainen et al. (1993), Aydoğan and Muradoğlu (1998) and Travlos et al. (2001) carried out in Sweden, Finland, Turkey and Cyprus, respectively, are some examples using the market-adjusted model for small markets. Even studies in large, developed markets document that the market-adjusted model has no disadvantages when compared with the market risk-adjusted model (Charest, 1978; Woolridge, 1982; Asquith \& Mullins, 1983; Asquith and Mullins, 1986). 
Equations (3) and (4) are used to find the daily average abnormal returns and cumulative abnormal returns for the event windows.

$$
\begin{aligned}
& A A R_{i t}=\frac{1}{N} \sum A R_{i t} \\
& C A R_{i}=\sum A A R_{i t}
\end{aligned}
$$

Here $A A R_{i t}$ is the average abnormal return of share $i$ on day $t$, and $C A R_{i}$ is the cumulative abnormal average return over an event window extending from $t=t$ to $t=T$.

Here $t=0$ represents the declaration date of cash dividends. As rumors about dividends circulate before the declaration date, it is possible to see price movement prior to the event. Therefore, the starting point of the event windows are set at 10 days prior to the announcement, which may indicate whether or not information was leaked prior to the declaration date.

Our data set includes not only events, but also the value of DPS. The amount of the payouts disclosed is specified as a fraction per share. Panel regression is used instead of classical event study analysis to test the relationship between dividend per share and CAR around declaration dates. DPS is employed as the independent variable in our regression. $C A R$ serves as the dependent variable, and is calculated using Equation (4). As taxes on dividends are proportional, they will not affect our results.

$D P S$ is regressed on CAR along the event windows. The regression model is formulated using Equation (5).

$$
C A R_{i}=\alpha+\beta D P S_{i}+e_{i}
$$

$C A R_{i}$ is the cumulative abnormal return of share $i$, and $D P S_{i}$ is the dividend per share in the windows extending from 10 days prior to and 30 days following the declaration date. In other words, we estimated equation (5) for each event windows.

In order to carry out panel regression analysis, cumulative abnormal returns are calculated for 17 event windows shown in the first column of Table 4. The first and the final days of the event windows are presented in their respective columns. The table also explains the reasons for opening the event windows and their possible

\begin{tabular}{|c|c|c|c|c|}
\hline \multicolumn{3}{|c|}{ Event windows } & \multirow{2}{*}{ Purpose of window } & \multirow{2}{*}{ Implications } \\
\hline No. & First day & Final Day & & \\
\hline 1 & $\mathrm{t}-10$ & $\mathrm{t}-1$ & \multirow{5}{*}{ Test for information leakage } & \multirow{6}{*}{$\begin{array}{l}\text { Examine efficiency in regulation and } \\
\text { effectiveness of supervision }\end{array}$} \\
\hline 2 & $t-5$ & $\mathrm{t}-1$ & & \\
\hline 3 & $\mathrm{t}-3$ & $\mathrm{t}-1$ & & \\
\hline 4 & $\mathrm{t}-2$ & $\mathrm{t}-1$ & & \\
\hline 5 & $\mathrm{t}-1$ & $\mathrm{t}-1$ & & \\
\hline 6 & $\mathrm{t}=0$ & $\mathrm{t}=0$ & \multirow{12}{*}{$\begin{array}{l}\text { Test for the market reaction dividend } \\
\text { and market efficiency }\end{array}$} & \\
\hline 7 & $\mathrm{t}=0$ & $t+1$ & & \multirow{11}{*}{$\begin{array}{l}\text { Test for the tax-clientele effect of dividends } \\
\text { and the duration of price adjustment }\end{array}$} \\
\hline 8 & $\mathrm{t}=0$ & $\mathrm{t}+2$ & & \\
\hline 9 & $\mathrm{t}=0$ & $\mathrm{t}+3$ & & \\
\hline 10 & $\mathrm{t}=0$ & $\mathrm{t}+5$ & & \\
\hline 11 & $\mathrm{t}=0$ & $\mathrm{t}+10$ & & \\
\hline 12 & $\mathrm{t}=0$ & $\mathrm{t}+12$ & & \\
\hline 13 & $\mathrm{t}=0$ & $t+13$ & & \\
\hline 14 & $\mathrm{t}=0$ & $t+15$ & & \\
\hline 15 & $\mathrm{t}=0$ & $t+20$ & & \\
\hline 16 & $\mathrm{t}=0$ & $t+25$ & & \\
\hline 17 & $\mathrm{t}=0$ & $t+30$ & & \\
\hline
\end{tabular}
implications.

Table 4. Reasons for opening and implications of event windows

\section{Empirical Results}

Empirical studies based on time series data make an assumption of that the underlying time series are stationary. But, time series in finance usually are non-stationary or in other terms they have unit root. Some researchers argue that if the time series variables are non-stationary, using data in levels may result in non-constant mean 
over time and residuals which are highly autocorrelated with low Durbin-Watson statistics (Kutty, 2010).

In this study, all variables tested whether they have unit root. For this purpose Levin, Lin and Chu (2002), Im, Pesaran and Shin (2003), Augmented Dickey-Fuller (1979) and the Phillip and Perron (1998) unit root tests are applied at the level for the individual intercept equation. According to test results none of variables have unit root. The selected results given in the Table 5 .

Table 5. Some selected results of unit root tests

\begin{tabular}{|c|c|c|c|c|c|c|c|c|c|c|c|c|}
\hline \multirow[b]{2}{*}{ Method } & \multicolumn{2}{|c|}{$D P S$} & \multicolumn{2}{|c|}{$C A R B 3$} & \multicolumn{2}{|c|}{$C A R B 1$} & \multicolumn{2}{|c|}{ CARO } & \multicolumn{2}{|c|}{ CARF1 } & \multicolumn{2}{|c|}{$C A R F 2$} \\
\hline & Stat. & Prob. & Stat. & Prob. & Stat. & Prob. & Stat. & Prob. & Stat. & Prob. & Stat. & Prob. \\
\hline Levin, Lin \& Chu t* & -103 & 0.00 & -339 & 0.00 & -210 & 0.00 & -587 & 0.00 & -861 & 0.00 & -317 & 0.00 \\
\hline Im, Pesaran and Shin W-stat & -137 & 0.00 & -149 & 0.00 & -225 & 0.00 & -152 & 0.00 & -201 & 0.00 & -143 & 0.00 \\
\hline $\mathrm{ADF}$ - Fisher Chi-square & 351 & 0.00 & 542 & 0.00 & 527 & 0.00 & 512 & 0.00 & 573 & 0.00 & 534 & 0.00 \\
\hline \multirow[t]{2}{*}{ PP - Fisher Chi-square } & 406 & 0.00 & 661 & 0.00 & 587 & 0.00 & 607 & 0.00 & 633 & 0.00 & 615 & 0.00 \\
\hline & \multicolumn{2}{|c|}{$C A R F 3$} & \multicolumn{2}{|c|}{ CARF5 } & \multicolumn{2}{|c|}{ CARF10 } & \multicolumn{2}{|c|}{ CARF 15} & \multicolumn{2}{|c|}{ CARF2O } & \multicolumn{2}{|c|}{ CARF 25} \\
\hline Method & Stat. & Prob. & Stat. & Prob. & Stat. & Prob. & Stat. & Prob. & Stat. & Prob. & Stat. & Prob. \\
\hline Levin, Lin \& Chu t* & -415 & 0.00 & -374 & 0.00 & -884 & 0.00 & -823 & 0.00 & -548 & 0.00 & -446 & 0.00 \\
\hline Im, Pesaran and Shin W-stat & -174 & 0.00 & -159 & 0.00 & -181 & 0.00 & -177 & 0.00 & -158 & 0.00 & -149 & 0.00 \\
\hline ADF - Fisher Chi-square & 609 & 0.00 & 584 & 0.00 & 550 & 0.00 & 565 & 0.00 & 555 & 0.00 & 549 & 0.00 \\
\hline PP - Fisher Chi-square & 702 & 0.00 & 692 & 0.00 & 669 & 0.00 & 688 & 0.00 & 711 & 0.00 & 729 & 0.00 \\
\hline
\end{tabular}

Note. All probabilities are significant at $1 \%$

As stated above, the main objective of this study is to examine whether or not DPS plays a significant role in the explanation of market reaction due to dividend announcements. Panel regression is performed to examine the relationship between DPS and abnormal returns based on event windows.

Table 6 displays the results of 17 panel regressions based on Equation (5). CAR of each regression are calculated based on event windows and regressed on DPS by using 902 observations of 118 listed companies during the period from 2003 to 2015.

Table 6. Summary of two-way fixed effect panel regression results

\begin{tabular}{|c|c|c|c|c|c|c|}
\hline \multicolumn{2}{|c|}{ Window } & \multirow{2}{*}{$\begin{array}{l}\text { Dependent Var. } \\
C A R 1 O B\end{array}$} & \multirow{2}{*}{$\begin{array}{r}\text { Coef. of DPS } \\
0.00104\end{array}$} & \multirow{2}{*}{$\begin{array}{r}\text { t-statistics } \\
0.93174\end{array}$} & \multirow{2}{*}{$\begin{array}{l}\mathbf{R}^{2} \\
0.21724\end{array}$} & \multirow{2}{*}{$\frac{\text { F-statistics }}{1.64596^{*}}$} \\
\hline $\mathrm{t}-10$ to $\mathrm{t}-1$ & {$[-10,-1]$} & & & & & \\
\hline $\mathrm{t}-5$ to $\mathrm{t}-1$ & {$[-5,-1]$} & $C A R 5 B$ & -0.00018 & -0.22170 & 0.17665 & $1.27244 * *$ \\
\hline$t-3$ to $t-1$ & {$[-3,-1]$} & $C A R 3 B$ & -0.00030 & -0.42990 & 0.16362 & 1.16023 \\
\hline$t-2$ to $t-1$ & {$[-2,-1]$} & $C A R 2 B$ & -0.00053 & -0.85157 & 0.18479 & $1.34437 * *$ \\
\hline $\mathrm{t}-1$ to $\mathrm{t}-1$ & {$[-1,-1]$} & CAR1B & -0.00077 & -1.35503 & 0.22050 & $1.67761^{*}$ \\
\hline t0 & {$[0,0]$} & CARO & -0.00065 & -1.31138 & 0.21727 & $1.64624 *$ \\
\hline t0 to $\mathrm{t}+1$ & {$[0,1]$} & CARIF & -0.00329 & $-4.71936^{*}$ & 0.25967 & $2.08024 *$ \\
\hline t0 to $t+2$ & {$[0,2]$} & $C A R 2 F$ & -0.00376 & $-4.86622 *$ & 0.24720 & $1.94755^{*}$ \\
\hline t0 to $t+3$ & {$[0,3]$} & CAR3F & -0.00362 & $-4.18390^{*}$ & 0.23521 & $1.82404 *$ \\
\hline to to $t+5$ & {$[0,5]$} & CAR5F & -0.00347 & $-3.58575^{*}$ & 0.22671 & $1.73878^{*}$ \\
\hline t0 to $t+10$ & {$[0,10]$} & CAR1OF & -0.00316 & $-2.46383 * *$ & 0.22178 & $1.69021^{*}$ \\
\hline t0 to $t+12$ & {$[0,12]$} & $C A R 12 F$ & -0.00302 & $-2.21086^{* *}$ & 0.23429 & $1.81472 *$ \\
\hline t0 to $t+13$ & {$[0,13]$} & $C A R 13 F$ & -0.00189 & -1.30138 & 0.22722 & $1.74380^{*}$ \\
\hline t0 to $t+15$ & {$[0,15]$} & CAR15F & -0.00150 & -0.95851 & 0.23341 & $1.80581 *$ \\
\hline t0 to $t+20$ & {$[0,20]$} & $C A R 20 F$ & -0.00106 & -0.60020 & 0.20307 & $1.51125^{*}$ \\
\hline t0 to $t+25$ & {$[0,25]$} & $C A R 25 F$ & -0.00181 & -0.86740 & 0.17778 & $1.28233^{* *}$ \\
\hline t0 to $t+30$ & {$[0,30]$} & CAR30F & -0.00136 & -0.60799 & 0.16703 & 1.18928 \\
\hline
\end{tabular}

Notes. * indicates statistical significance of $1 \%$ level, and ** indicates statistical significance of $5 \%$. The data are unbalanced, so the two-way random-effects model could not be run due to missing data. In the one-way random-effects model, model Hausman test favored the fixed effects model. F means forward, while $B$ means backward. 


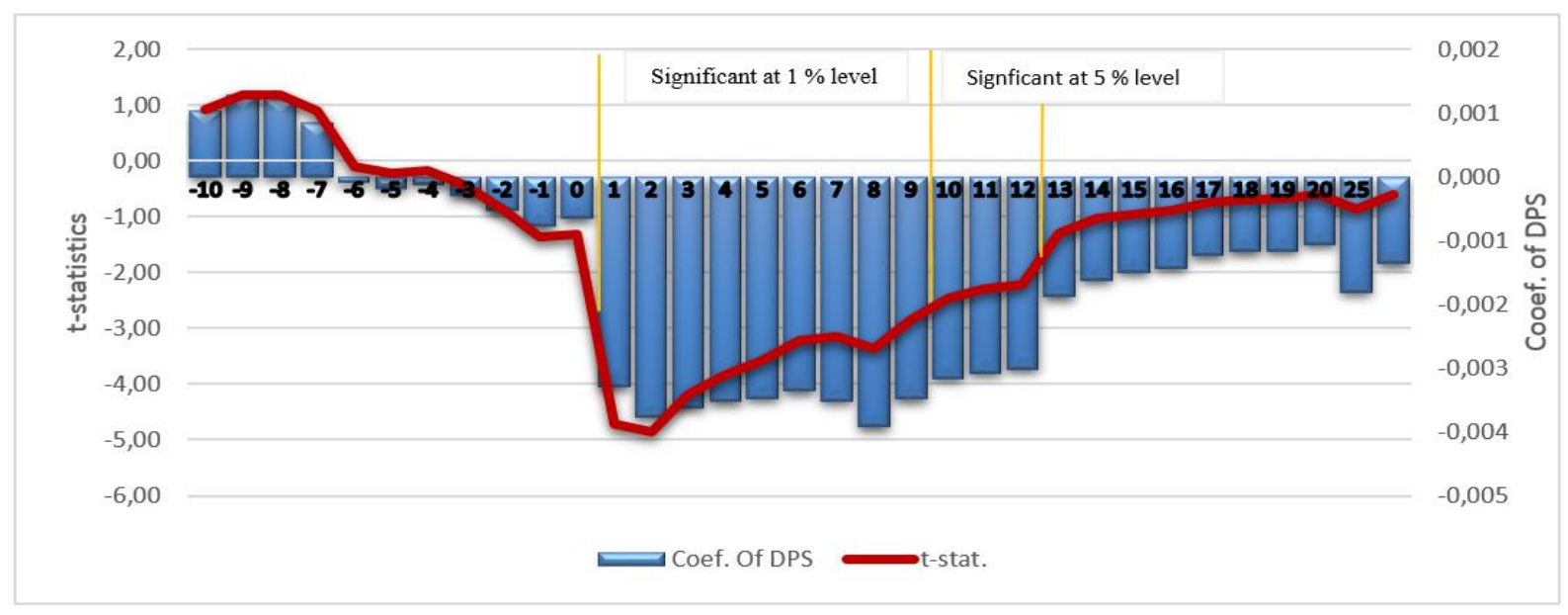

Figure 1. Graphical representation of coefficients of DPS and t-statistics

Note. Figure 1 displays the results of the panel regressions in different event windows.

Table 6 and Figure 1 reveal that cash dividend announcements lead to significant, negative abnormal returns following the announcements. In other words, DPS causes negative market reaction when dividends are announced. In the event window [0, 1] (prior to day 1), the coefficient of DPS is -0.00329 with a significance of $1 \%$. In the event window [0, 2], the coefficient of DPS is -0.00376 with a significance of $1 \%$. The most powerful and significant relationship between DPS and CAR is during this window (as some announcements are made after close of session, day 1 should also be considered day 0 ). As such, there is negative, statistically significant relationship between DPS and abnormal returns after the announcement of dividends starting with day 1 . This statistically significant relationship continues up to day 9 at a $1 \%$ level with decreasing rates and from day 10 to day 12 at a $5 \%$ level. Although the sign of the relationship is negative, there is no statistically significant relationship between $D P S$ and $C A R$ prior to day 0 or after day 13 .

To sum up, market reacts negatively to cash dividends after disclosing of dividend. Declarations of higher cash dividends per share results in a significantly higher, negative market reaction, while declarations of lower cash dividends per share result in significantly lower, negative market reaction. When a company announces cash dividends, shareholders start to sell their holdings in order to avoid more taxation in the future. Therefore, market prices decrease. The lower dividend announcement results in lower market reaction in terms of selling shares by shareholders or opportunity to new shareholders start to buy. The lower dividend helps shareholders to avoid more taxes due to high tax rate on dividend yield as compared to capital gain. Thus, shareholders who prefer lower dividend benefit from tax saving. Thus, the results support the tax-clientele effect hypothesis. This is most likely due to the fact that capital gains are taxed at a lower rate than dividend yields in Turkey. Shareholders prefer earnings to be retained by the firm in light of favorable taxation of capital gains. Higher cash dividends result in a higher tax burden for shareholders in the future; therefore, they give a negative response by selling their shares. Conversely, lower cash dividends lead to a higher proportion of earnings retained by the firm, which suits shareholder tax preferences.

The statistically negative relationship between DPS and CAR following the announcement of dividends supports the findings of Günalp, Kadıoğlu and Kılıç (2010) but do not support Yılmaz and Selçuk (2010) for Turkey. The results also suggest that there is no significant information leakage prior to declaration dates. When the results are contrasted with the findings of Aydoğan and Muradoğlu (1998), it seems that the inefficiency of the market has decreased over time; the adjustment of prices to new information appears to start at day 0 , and the most significant adjustment takes place between day 0 and day 2. The negative relationship between dividend announcements and share price also found by Karim (2010) for London Stock Exchange, Vazakidis and Athianos (2010) for Athens Stock Exchange, Mamun et al. (2013) for Bangladesh, Samwel et al. (2014) for Nairobi Securities Exchange and Abbas (2015) for Damascus Stock Exchange. On the other hand our findings do not support those of Lukose and Rao (2010), Akron (2011), Miletic (2011), Sheikhbahaei et al. (2011), Suwanna (2012), Demontis (2013), Perepeczo (2014), Liu and Chi (2014), Pan et al. (2014) and Asiri (2014). 


\section{Conclusion}

Although it is still a puzzle as to whether or not dividends affect a firms' worth or share prices, many capital market regulatory bodies accept that dividends has an effect on stock price. Three major theories attempt to explain the relationship between the dividend changes and firms' share prices: The information signaling theory, the free cash flow hypothesis and the dividend clientele effect hypothesis.

There are limited studies on this relationship within emerging markets such as Turkey. The few studies carried out in Turkey have not used recent data or advanced methodology, and generally, they have not used exact declaration dates. This study utilizes more recent data covering the period from 2003 to 2015 including 902 events of 118 companies listed on Borsa Istanbul. Market reactions to announcements of cash dividends are examined by analyzing the relationship between dividend per share and cumulative abnormal returns around the declaration date. In order to determine this relationship, we performed two-way fixed effect panel regression analysis.

We have found that there is a significant, negative relationship between dividend per share and abnormal returns following the announcement showing that market reacts negatively to dividend announcement. The results support the tax-clientele effect hypothesis. This is most likely due to the fact that the capital gains are taxed at a lower rate than dividend yields in Turkey. When companies announce cash dividends, shareholders start selling their holdings in order to avoid more taxation in the future. Furthermore, it is found that there is no significant information leakage prior to declaration dates.

It would be beneficial for future studies to focus on determinants of dividend payouts in Turkey.

\section{References}

Abbas, G. (2015). Stock Prices Reaction to Dividend Announcements: A Study on Listed Companies in the Damascus Securities Exchange. International Journal of Academic Research in Accounting, Finance and Management Sciences, 5(1), 130-136. http://dx.doi.org/10.6007/IJARAFMS/v5-i1/1550

Aharony, J., \& Swary, I. (1980). Quarterly dividend and earnings announcements and stockholders' returns: An empirical analysis. Journal of Finance, 35, 1-12. http://dx.doi.org/10.1111/j.1540-6261.1980.tb03466.x

Akhigbe, A., \& Madura, J. (1996). Dividend policy and corporate performance. Journal of Business Finance and Accounting, 23, 1267-1287. http://dx.doi.org/10.1111/1468-5957.00079

Akron, S. (2011). Market Reactions to Dividend Announcements under Different Business Cycles. Emerging Markets Finance and Trade, Supplement 5(47), 72-85. http://dx.doi.org/10.2753/REE1540-496X4706S505

Ang, J. S. (1975). Dividend policy: Informational content or partial adjustment. Review of Economics and Statistics, 57, 65-70. http://dx.doi.org/10.2307/1937864

Armitage, S. (1995). Event Study Methods and Evidence on Their Performance, Journal of Economic Surveys, 8 , 25-52. http://dx.doi.org/10.1111/j.1467-6419.1995.tb00109.x

Asiri, B. K. (2014). Dividend Announcement: Is It a Good News to the Bahrain Bourse? International Journal of Economics and Finance, 6(12), 223-248. http://dx.doi.org/10.5539/ijef.v6n12p228

Asquith, P., \& Mullins, D. W. (1983). The impact of initiating dividend payments on shareholders' wealth. Journal of Business, 56, 77-96. http://dx.doi.org/10.1086/296187

Asquith, P., \& Mullins, D. W. (1986). Signalling with Dividends, Stock Repurchases, and Equity Issues. Financial Management, 15, 27-44. http://dx.doi.org/10.2307/3664842

Aydoğan, K., \& Muradoğlu, G. (1998). Do Markets Learn from Experience? Price Reaction to Stock Dividends in the Turkish Market. Applied Financial Economics, 8, 41-49. http://dx.doi.org/10.1080/096031098333230

Batchelor, R., \& Orakcioglu, I. (2003). Event-Related GARCH: The Impact of Stock Dividends in Turkey. Applied Financial Economics, 13, 295-307. http://dx.doi.org/10.1080/09603100210138547

Bhattacharya, S. (1979). Imperfect Information, Dividend Policy, and the 'Bird in the Hand' Fallacy. Bell Journal of Economics, 10, 259-270. http://dx.doi.org/10.2307/3003330

Black, F. (1976). The dividend puzzle. Journal of Portfolio Management, 2, 72-77. http://dx.doi.org/10.3905/jpm.1976.408558

Black, F., \& Scholes, M. (1974). The effects of dividend yield and dividend policy on common stock prices and returns. Journal of Financial Economics, 1, 1-22. http://dx.doi.org/10.1016/0304-405X(74)90006-3

Brown, S. J., \& Warner J. B. (1980). Measuring security price performance. Journal of Financial Economics, 8, 
205-258. http://dx.doi.org/10.1016/0304-405X(80)90002-1

Charest, G. (1978). Dividend information, stock returns and market efficiency-II. Journal of Financial Economics, 6, 297-330. http://dx.doi.org/10.1016/0304-405X(78)90033-8

Deangelo, H., \& Deangelo, L. (1990). Dividend Policy and Financial Distress: An Empirical Investigation of Troubled NYSE Firms, Journal of Finance, 55, 1415-1431. http://dx.doi.org/10.1111/j.1540-6261.1990.tb03721.x

Deangelo, H., \& Deangelo, L. (2000). Controlling stockholders and the disciplinary role of corporate payout policy: A study of the Times Mirror Company. Journal of Financial Economics, 56, 153-207. http://dx.doi.org/10.1016/S0304-405X(00)00039-8

Demontis, M. D. B. (2013). A study of the Dividend Signaling theory on the Scandinavian market. MSc Dissertation Thesis, Business and Social Sciences, Aarhus University

Dennis, D., \& McConnell, J. (1986). Corporate mergers and security returns. Journal of Financial Economics, 16, 143-187. http://dx.doi.org/10.1016/0304-405X(86)90059-0

Dennis, D. J., Dennis, D. K., \& Sarin, A. (1994). The information content of dividend changes: Cash flow signalling, overinvestment, and dividend clienteles. Journal of Financial and Quantitative Analysis, 29, 557-587. http://dx.doi.org/10.2307/2331110

Dickey, D. A., \& Fuller, W. A. (1979). Autoregressive Time Series with a Unit Root. Journal of the American Statistical Association, 74, 427-431.

Easterbrook, F. H. (1984). Two agency-cost explanations of dividends. American Economic Review, 74, 650-659.

Gonedes, N. J. (1978). Corporate signalling, external accounting, and capital market equilibrium: Evidence on dividends, income, and extraordinary items. Journal of Accounting Research, 16, 26-79. http://dx.doi.org/10.2307/2490411

Gregory, A., Matatko, J., \& Tonks, I. (1997). Detecting information from directors' trades: Signal definition and variable size effects. Journal of Business Finance \& Accounting, 24, 309-342. http://dx.doi.org/10.1111/1468-5957.00107

Günalp, B., Kadığlu, E., \& Kılıç, S. (2010). Nakit Temettü Bilgisinin Hisse Senedi Getirisi Üzerinde Önemli Bir Etkisi Olup Olmadığının İMKB'de Test Edilmesi, Hacettepe University Journal of Economics and Administrative Sciences, 28(2), 47-69.

Hillier, D., \& Marshall, A. P. (2002). Are Trading Bans Effective? Exchange Regulation and Corporate Insider Trading. Journal of Corporate Finance, 8, 393-410. http://dx.doi.org/10.1016/S0929-1199(01)00046-3

Im, K.S., Pesaran, M. H., \& Shin, Y. (2003). Testing for unit roots in heterogeneous panels. Journal of Econometrics, 115(1), 53-74. http://dx.doi.org/10.1016/S0304-4076(03)00092-7

Jensen, G. (1986). Agency costs of free cash flow, corporate finance, and takeovers. American Economic Review, 76, 323-329. http://dx.doi.org/10.1017/CBO9780511609435.005

John, K., \& Williams, J. (1985). Dividends, dilution, and taxes: A signalling equilibrium. Journal of Finance, 40, 1053-1070. http://dx.doi.org/10.1111/j.1540-6261.1985.tb02363.x

Kalay, A., \& Loewenstein, U. (1985). Predictable events and excess returns: the case of dividend announcements. Journal of Financial Economics, 14, 423-449. http://dx.doi.org/10.1016/0304-405X(85)90007-8

Karim, M. (2010). Announcement Effect of Dividend on the Stock Price of Enlisted Companies in Developed Countries: A Comparative Study between London Stock Exchange \& New York Stock Exchange. http://dx.doi.org/10.2139/ssrn.1624363

Kutty, G. (2010). The Relationship Between Exchange Rates and Stock Prices: The Case of Mexico. North American Journal of Finance and Banking Research, 4(4), 1-13.

La Porta, R., Lopez-De-Silanes, F., Shleifer, A., \& Vishny, R. (2000). Agency problems and dividend policies around the world. Journal of Finance, 55, 1-33. http://dx.doi.org/10.1111/0022-1082.00199

Levin, A., Lin, C. F., \& Chu, J. (2002). Unit root tests in panel data: Asymptotic and finite-sample properties. Journal of Econometrics, 108(1), 1-24. http://dx.doi.org/10.1016/S0304-4076(01)00098-7

Liljeblom., E. (1989). The Informational Impact of Announcements of Stock Dividends and Stock Splits. Journal of Business Finance and Accounting, 16, 681-697. 
http://dx.doi.org/10.1111/j.1468-5957.1989.tb00047.x

Lintner, J. (1956). Distribution of incomes of Corporations Among dividends, Retained Earnings and Taxes. American Economic Review, 5, 97-113.

Liu, J. Y., \& Chi, D. J. (2014). Stock Market Reaction to Various Dividend Announcements: Which Kind of Dividend Announcement is More Significant? Journal of Testing and Evaluation. http://dx.doi.org/10.1520/JTE20120327

Lukose, J., \& Rao, S. N. (2010). Dividend changes and profitability: An empirical study of Indian manufacturing firms. The IUP Journal of Applied Finance, 16(1), 5-26.

Mamun, A., Hoque, N., \& Mamun, A. M. A. (2013). Stock Price Reaction to Dividend Announcement: the Case of Bangladesh Capital Market. Journal of Economics and Sustainable Development, 4(8), 89-98.

Martikainen, T., Rothovlus, T., \& Yli-Olli, P. (1993). On the Individual and Incremental Information Content of Accrual Earnings, Cash Flows and Cash Dividends in the Finnish Stock Market. European Journal of Operational Research, 68, 318-333. http://dx.doi.org/10.1016/0377-2217(93)90188-S

Masulis, R. W. (1980). The effects of capital structure changes on security prices: A study of exchange offers. Journal of Financial Economics, 8, 139-178. http://dx.doi.org/10.1016/0304-405X(80)90015-X

Miletic, M. (2011). Stock Price Reaction to Dividend Announcement in Croatia. Ekonomska Istrazivanja/Economic Research, 24(3), 147-156.

Miller, M., \& Modigliani, F. (1961). Dividend policy, growth, and the valuation of shares. Journal of Business, 4, 411-433. http://dx.doi.org/10.1086/294442

Miller, M., \& Scholes, M. (1982). Dividends and taxes: Some empirical evidence. Journal of Political Economy, 90, 1118-1141. http://dx.doi.org/10.1086/261114

Miller, M. H., \& Rock, K. (1985). Dividend policy under asymmetric information. Journal of Finance, 40, 1031-1051. http://dx.doi.org/10.1111/j.1540-6261.1985.tb02362.x

Muradoğlu, G. \& Aydoğan, K. (2003). Trends in market reactions: Stock dividends and rights offerings at Istanbul stock exchange. The European Journal of Finance, 9, 41-60. http://dx.doi.org/10.1080/13518470110047611

Pan, R., Tang, X., Tan, Y., \& Zhu, Q. (2014). The Chinese Stock Dividend Puzzle. Emerging Markets Finance \& Trade, 50(3), 178-195. http://dx.doi.org/10.2753/REE1540-496X500310

Perepeczo, A. (2014). Shareholders' Preferences, Business Cycles and Market Reactions to Dividend Announcements In Public Companies -- Empirical Evidence. Transformation in Business \& Economics, 13(2B), 648-660.

Pettit, R. (1972). Dividend announcements, security performance, and capital market efficiency. Journal of Finance, 5, 993-1007. http://dx.doi.org/10.1111/j.1540-6261.1972.tb03018.x

Pettit, R. R. (1976). The impact of dividend and earnings announcements: Reconciliation. Journal of Business, 49, 86-96. http://dx.doi.org/10.1086/295813

Phillips, P. C. B., \& Perron, P. (1988). Testing for a Unit Root in Time Series Regression. Biometrika, 75(2), 335-346. http://dx.doi.org/10.1093/biomet/75.2.335.

Rozeff, M. S. (1982). Growth, Beta, and Agency Costs as Determinants of Dividend Payout Ratios'. Journal of Financial Research, 5, 249-259. http://dx.doi.org/10.1111/j.1475-6803.1982.tb00299.x

Samwel, K. N., Simiyu, J., Galo, N., \& Mbogo, J. (2014). The Effect of Dividend Announcement on Share Price Changes for Companies listed at Nairobi Securities Exchange, Kenya. Research Journal of Finance and Accounting, 5(17), 243-254.

Sharma, R. V. (2011). Stock Price Behaviour around Dividend Announcements: An Event Study Methodology. The XIMB Journal of Management, 8(2), 23-32.

Sheikhbahaei, A., Osman, H. M., \& Rahman, A. I. (2012). Information Content in Dividend Announcements. A Test of Market Efficiency in Malaysian Market. International Business Research. 5(12), 38-45. http://dx.doi.org/10.5539/ibr.v5n12p38

Sivakumar, K., \& Waymire, G. (1994). Insider trading following material news events: Evidence from earnings. Financial Management, 23, 23-32. http://dx.doi.org/10.2307/3666053 
Suwannaa T. (2012). Impacts of Dividend Announcement on Stock Return. Procedia - Social and Behavioral Sciences 40, 72-725. http://dx.doi.org/10.1016/j.sbspro.2012.03.255

Travlos, N., Trigeorgis, L., \& Vafeas, N. (2001). Shareholder Wealth Effects of Dividend Policy Changes in an Emerging Stock Market: The Case of Cyprus. Multinational Finance Journal, 5, 87-112. http://dx.doi.org/10.17578/5-2-1

Vazakidis, A., \& Athianos, S. (2010). Do Dividend Announcements Affect The Stock Prices in The Greek Stock Market? International Journal of Economic Sciences \& Applied Research, 3(2), 57-77.

Venkatesh, P. C. (1989). The impact of dividend initiation on the information content of earnings announcements and returns volatility. Journal of Business, 62, 175-197. http://dx.doi.org/10.1086/296458

Watts, R. (1973). The information content of dividends. Journal of Business, 46, 191-211. http://dx.doi.org/10.1086/295525

Woolridge, J. R. (1982). The information content of dividend changes. Journal of Financial Research. 5, 237-247. http://dx.doi.org/10.1111/j.1475-6803.1982.tb00298.x

Yılmaz, A. A., \& Selçuk, E. A. (2010). Information Content of Dividends: Evidence from Istanbul Stock Exchange. International Business Research, 3(3), 126-132.

\section{Copyrights}

Copyright for this article is retained by the author(s), with first publication rights granted to the journal.

This is an open-access article distributed under the terms and conditions of the Creative Commons Attribution license (http://creativecommons.org/licenses/by/3.0/). 